\title{
Proximate and Mineral Composition of Nsala Bakala (Dracaena camerooniana Baker) Leaves, Stems and Roots from Nzenze Forest in Uíge Province, Angola
}

\author{
Monizi Mawunu, Thea Lautenschläger, Koto-te-Nyiwa Ngbolua, Lukoki Luyeye, \\ and Luyindula Ndiku
}

\section{ABSTRACT}

The aim of the present work was to perform nutritional analysis of Dracaena camerooniana Baker. Nutrient determination was carried out according to standard methods. The nutritional profile of the leaves, roots and stems of $D$. camerooniana showed that these organs are rich in fibre (14.20-53.65\%), proteins (4.47-18.58\%), lipids (1.53-5.42\%) carbohydrates (23.67-70.94\%), ash $(2.17-15.59 \%)$ and mineral elements, namely, K (535.07-1690.00 mg/100 g), Ca (315.87-1459.97 mg/100 g), Mg (95.41498.83 mg/100 g), P (76.72-149.56 mg/100 g), Na (105.83-113.60 mg/100 g), Se (75.87-128.51 mg/100 g), Fe (40.88-228.30 mg/100 g), Mn (7.41$11.39 \mathrm{mg} / 100 \mathrm{~g}), \mathrm{Zn}(2.94-5.83 \mathrm{~g} / 100 \mathrm{~g}), \mathrm{Cu}(2.30-2.80 \mathrm{mg} / 100 \mathrm{~g})$, and Co $(0.65-2.80 \mathrm{mg} / 100 \mathrm{~g})$ The different levels of nutrient contents observed in the analyzed organs of $D$. camerooniana would be attributed to the accumulative capacities of the plant organs. It is therefore recommended (desirable) that further studies be conducted to determine the content of anti-nutritional factors in this plant on the one hand and to evaluate its pharmaco-biological properties on the other. Domestication of the plant should be done to ensure its conservation with the support of local farmers. Thus, the use of biotechnology would allow the availability of healthy plant material for both present and future generations.

Keywords: Dracaena camerooniana, nutritional and mineral composition, Uíge Province, Angola.

\section{INTRODUCTION}

Food and Agricultural Organization (FAO) reports that at least one billion people are thought to use wild foods in their diet [1]. Forests provide livelihoods and food for some 300 million people in the form of non-timber forest products (NTFPs). In general, food security and NTFPs are strongly interlinked in rural communities, especially for the most vulnerable groups [2], even among agricultural communities [3]. Urban communities also rely on wild foods [4].

Wild edible plants (WEPs) refer to species that are neither cultivated nor domesticated but are available from their wild natural habitat and used as sources of food [5].
Published Online: July 31, 2021

ISSN: 2684-5199

DOI: 10.24018 /ejbio.2021.2.4.225

\section{Mawunu}

Department of Agronomy, Polytechnic Institute of Kimpa University, Kimpa Vita University, Uíge, Republic of Angola.

Botanic garden of Kimpa Vita University, Uíge, Republic of Angola.

(e-mail: m.mawunu2000@ gmail.com)

T. Lautenschläger

Institut für Botanik Technische

Universität, Dresden, Germany.

(e-mail:

thea.lautenschlaeger@tu-dresden.de)

K. N. Ngbolua*

Department of Biology, Faculty of Science, University of Kinshasa, Democratic Republic of Congo.

(e-mail: jpngbolua ${ }^{\circledR}$ unikin.ac.cd)

L. Lukoki,

Department of Biology, Faculty of

Science, University of Kinshasa,

Democratic Republic of Congo.

(e-mail: Felicienlukokiluyeye ${ }^{\circledR}$ yahoo.fr)

N. Luyindula,

Commissariat General Atomic

Energy/Regional Center for Nuclear Studies in Kinshasa (CGEA/CREN-K, Division of Life Science, Department of Biotechnology and Molecular Genetic, Democratic Republic of Congo.

(e-mail: sluyindula@yahoo.fr)

*Corresponding Author
Wild edible plants (WEPs) are one of the alternative sources of healthy and nutritious food, and they are vitally important in supporting the global food basket in all parts of the world in general and in sub-Saharan Africa in particular. Wild edible plants are those plants with edible parts that grow naturally on farmland and on fallow or uncultivated land [6]. Ancient times, wild edible plants have sustained human populations in each of the inhabited continents.

Dietary use of wild fruits, nuts, seeds, and leaves appearing numerous historical records [7]. According to Sekeroglu et al. [8], different wild edible plants have played a significant role in different geographical regions of the world throughout human history. 
These wild edible plants have played a significant role in supplying food and nutritional requirements and increasing the health status of poor communities in many rural parts of the world [9].

Wild edible plants are of vital importance in all regions of the world to support the global food basket [10]. Wild edible plants play an important role in the daily lives of local people in terms of food and income and also, they can be important commercial products in local and regional markets and as such contribute to local cash income and to the improvement of people's well-being. In addition, employment can be obtained through the sale or exchange of their fruits, roots, seeds, bark, leaves, hoots, juices, and local drinks [11]-[14].

Studies reveal that, wild edible plants are rich in minerals, vitamins, carbohydrates, proteins, fats, and fiber and in addition they are used as remedy for various diseases [15] and their nutritional values may be superior to those domesticated varieties [16], [17]. From the nutritional perspectives, wild edible plants are sources of many micronutrients commonly lacking in staple-dependent diets in developing countries, which are important for human health and development [18]. Minerals with critical significance in human nutrition and health are essential nutrients for normal physiological functions of the body [19].

The wild flora of Northern Angola abounds in numerous plants with multiple uses for human and his habitat. These plants are used for food, human and animal health, handicrafts, furniture, house construction and others [20].

The forests serve as a prime habitat for many wild edible plants [11] that fulfill the needs of the communities throughout the year. Many of these inexpensive edible plants are consumed by the local communities yet many remains unutilized, and the nutritional potential of these species are yet to be studied. Therefore, there is an urgent need to conserve adopting possible strategies and advocate sustainable utilization of these wild edible plants for future generation. At the same time, it is also essential to explore the nutritional content of this wild edible plant so as to validate the scientific basis of consumption of this species.

Comprehensive data on the composition of foods is an essential first step towards the enhancement and preservation of wild foods and their natural habitats. This is the reason for this study.

The aim of the study is to determine the proximate and mineral composition of Dracaena camerooniana leaves, stems and roots.

Besides, we have evaluated the functional properties of this plant to better understand its importance in human's nutrition. The results and parameters could then provide fundamental bases for the nutritive exploitation, reducing food insecurity, and malnutrition problems and also increasing dietary diversity within local communities and beyond.

\section{Materials AND MethodS}

\section{A. Plant Material}

Fresh plant material of this plant species, mentioned in Monizi et al. [12] was collected in the Nzenze (Songo) forest, in the Angolan province of Uíge, cleaned, immediately dried in a drying cabinet (HTD 100 Bench Top, LinTek) at $30^{\circ} \mathrm{C}$, then vacuum-sealed, stored in a freezer and later sent to Kinshasa, RDC, for analysis. At the same time, herbarium voucher of the plant species mentioned was prepared, identified, and stored in the Herbarium Dresdense (DR, voucher no. 056361). The organs exploited for food purposes are the leaves (Fig. 1 a) the tuberous roots (Fig. 1 b) and the Plant (leafy stem) of D. camerooniana (Fig. 1 c).

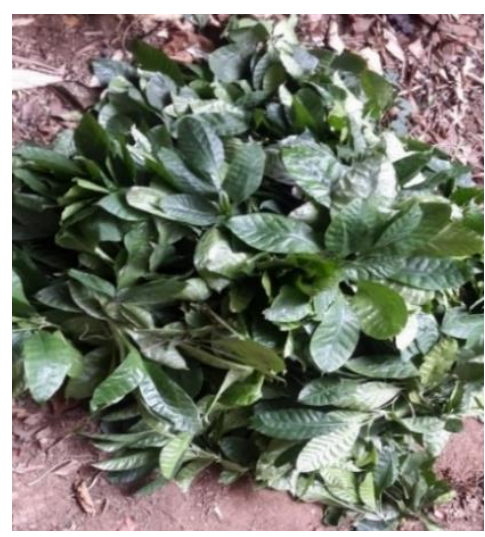

(a)

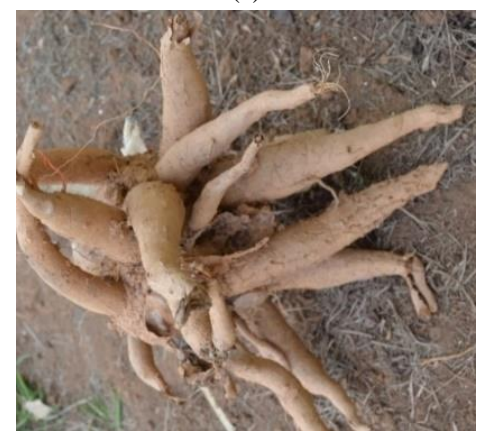

(b)

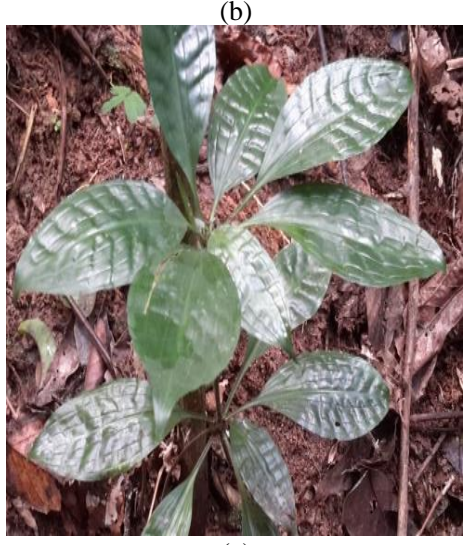

(c)

Fig. 1. Photo of D. camerooniana: (a) leaves, (b) roots, (c) stems.

\section{B. Analytical Methods}

\section{1) Moisture}

The determination of moisture $(\mathrm{g} / 100 \mathrm{~g}$ ) was performed by weight loss using method previous described [21].

\section{2) Crude Protein}

Total nitrogen and proteins contents were determined according to Kjeldahl method [21].

\section{3) Estimation of Total Fibers}

Crude fibers the raw materials or cellulosic fibers were measured following Kurschner method based on attack under reflux condenser of sample powder by mixing acetic and nitric acids [21]. 


\section{4) Total Lipids}

Total lipids were extracted by organic solvent (n-hexane) under heat and measurements (g/100 g sample) using Soxhlet method [21].

\section{5) Estimation of Total Carbohydrates}

The total percentage of carbohydrate content in the sample of D. camerooniana was determined by the modified method of Asaduzzaman et al. [22] after deproteinized and delipidized.

This method involved adding the total values of crude protein, lipid, crude fiber, residual moisture, and ash constituents of the sample and subtracting it from 100. The value obtained is the percentage carbohydrate constituent of the sample. Thus:

$$
\begin{gathered}
\% \text { carbohydrate }=100-(\% \text { residual moisture }+\% \text { crude } \\
\text { fiber }+\% \text { protein }+\% \text { lipid }+\% \text { ash })
\end{gathered}
$$

\section{6) Ash Content and Mineral Composition}

The total ash was determined by incinerating a known amount of the sample in an electric muffle furnace until obtaining a white ash. Briefly, $5 \mathrm{~g}$ of each sample was weighed in a silica crucible and heated in muffle furnace for about 5-6 hours at $500{ }^{\circ} \mathrm{C}$. It was cooled in a desiccator and weighed. It was heated again in the furnace for half an hour, cooled and weighed. This was repeated consequently till the weight became constant (ash became white or grayish white). Weight of residue gave the ash content [21].

The mineral contents were determined by Inductively Coupled Argon Plasma Optical Emission Spectrometry (ICPOES) [Optima 8300 Perkin Elmer, USA] as previously reported by [23]. Briefly, the sample $(0.3 \mathrm{~g})$ was dissolved in $5 \mathrm{~mL}$ of distilled water placed in PM60 Teflon bombs (Analytik Jena 40 Bar) and heated at $60{ }^{\circ} \mathrm{C}$ and $10 \mathrm{~mL}$ of nitric acid $\left(\mathrm{HNO}_{3} 65 \%\right)$ (Merck) was then added.

The resulting mixture was incubated at room temperature for 30 minutes to allow the oxidation to occur and later the bombs were covered first with caps and then stripped with $\mathrm{HNO}_{3} / \mathrm{H} 2 \mathrm{O}(\mathrm{v} / \mathrm{v}, 1: 1)$. The bombs were placed in the high frequency microwave mineralizer (Analytikjena AG Top wave: $2.5 \mathrm{Ghz}$, Germany) controlled by microcomputer by choosing the vegetable leaves, roots, and stems mode as a digestion mode at $180^{\circ} \mathrm{C}, 50$ bars for an hour. At the end of mixing, the digester was stopped by letting the bombs rest for 3 hours until completely cooled. The cooled analyte was thus carefully transferred by filtration on Whatman filter paper, bombs to $50 \mathrm{~mL}$ volumetric flasks previously stripped. The calibration of the ICP-OES was performed using the working standard prepared from the commercially available standard multi-element solution 3 at two points $(1 \mathrm{mg} / \mathrm{L}$ and $2.5 \mathrm{mg} / \mathrm{L}$, Perkin Elmer, USA). The most appropriate wavelength, gaseous argon flow, plasma stabilization and other ICP-OES instrument parameters for minerals were selected and measurements were made in the linear range of the working standards used for calibration. The operating conditions were Power of Rf (1500 Watt); Plasma gas flow (Ar): $8 \mathrm{~L} / \mathrm{min}$; Nebulizer (0.70 L /min); Auxiliary gas flow (Ar): $0.2 \mathrm{~L} / \mathrm{min}$; Viewing size $(5-22 \mathrm{~mm})$; Copy and playback time: $1-5 \mathrm{~s}$ (maximum $45 \mathrm{~s}$ ); Flow time: 1s (maximum $10 \mathrm{~s}$ ); View: Radial.

\section{7) Estimation of Energy Value}

The energy value of the samples was determined by multiplying the protein content by 4 , carbohydrate content by 4 and fat content by 9 [24].

Energy Value $=($ Crude protein $\times 4)+($ Total carbohydrate $\times 4)+($ Crude fat $\times 9)$

\section{Statistical Analysis}

All assays were carried out in triplicate and the values were obtained by calculating the average of three experiments and data are presented as Mean.

\section{RESULTS AND DISCUSSION}

\section{A. Chemical Composition}

1) Physico-chemical Composition of D. camerooniana Organs

Table I shows the physico-chemical composition of the three organs analyzed (leaves, roots, and stems) of $D$. camerooniana.

TABLE I: PHYSICO-CHEMICAL COMPOSITION (\%) AND ENERGY VALUE (KCAL) OF D. CAMEROONIANA ORGANS

\begin{tabular}{cccc}
\hline \multirow{2}{*}{$\begin{array}{c}\text { Physico-chemical } \\
\text { parameters }\end{array}$} & \multicolumn{3}{c}{ Content (\%) of organs } \\
& Roots & D. camerooniana \\
\cline { 2 - 4 } & 81.78 & 77.73 & 86.89 \\
\hline Moisture & 8.95 & 10.25 & 4.77 \\
Residual moisture & 2.17 & 3.90 & 15.59 \\
Ashes & 1.53 & 1.76 & 5.42 \\
crude fat & 4.47 & 6.77 & 18.58 \\
Crude proteins & 11.94 & 53.65 & 14.20 \\
Crude fibres & 70.94 & 23.67 & 41.44 \\
Carbohydrates & 315.41 & 137.60 & 288.86 \\
Energy (kcal) & & & Leaves \\
\hline
\end{tabular}

Mean values of three experiments.

The leaves of $D$. camerooniana had a higher moisture content $(86.89 \%)$ than the roots $(81.78 \%)$ and stems $(77.73 \%)$

The moisture content found in this study is higher than that reported by Ilodibia et al. [25] for D. mannii (leaves: $67.05 \pm 0.33 \%$; stem: $15.01 \pm 0.48 \%$; roots: $16.08 \pm 0.16 \%$ ) and D. arborea species (leaves: $69.07 \pm 0.45 \%$; stem: $30.15 \pm 0.39 \%$; roots: $20.16 \pm 0.43 \%$ ). When food is consumed, some of the water it contains is absorbed by the body. According to the Food and Nutrition Board [26], water is an essential component of many foods, with $20 \%$ of total water consumption coming from food. Dorosz [27] reports moisture values of $70-90 \%$ for leafy vegetables while Depesay [28] reports moisture content in the range $85-95 \%$.

The latter correspond to those found in this study. The data of the present study reveal that the analyzed organs of $D$. camerooniana are rich in water. The high water content found in the leaves and roots of $D$. camerooniana indicates that these organs are more vulnerable to spoilage as foods with high water content are more perishable [29].

Foods with a water content of 50-95\% are called high water content foods [30].

The organs of $D$. camerooniana analyzed in this study are rich in water.

The leaves of $D$. camerooniana are richer (15.59 DM) in ash than the stem $(3.90 \%)$ and roots $(2.17 \%)$. The ash value 
reported by Shukla et al. [31] on Dracaena reflexa leaves $(8.02 \pm 0.25 \%)$ is lower than that found in the present study. Compared to other edible leaves in the region, the ash content found in this study is higher than those reported by Mawunu et al. [17] for Mondia whitei (12.93\%) and Pyrenacantha klaineana $(6.74 \%)$ leaves. The ash content is a good indicator for the concentration of minerals in food. Minerals in feed are necessary for good growth and health of humans and livestock. Indeed, feeds with a high ash content are rich in mineral constituents [16].

Moreover, these mineral elements are necessary for human biological processes: they regulate osmotic pressure and protect against many diseases, such as cancer and cardiovascular disease; they are ingredients of the skeleton and enzyme systems [32]. Thus, the leaves and roots of $D$. camerooniana are an excellent source of mineral elements for pregnant women, the elderly, teenagers, and growing children, while the stems can be used as fodder for livestock [33].

The results on lipid content reveal a difference between $D$. camerooniana leaves $(5.42 \pm 0.07 \% \mathrm{DM})$, stem $(1.76 \pm 0.12 \%)$ and roots $(1.53 \pm 0.11 \%)$, respectively. Furthermore, the lipid content found in this study is higher than those reported by Ilodibia et al. [25] for leaves $(0.80 \pm 0.25 \%)$, stem $(0.50 \pm 0.15 \%)$, roots $(0.02 \pm 0.23 \%)$ of $D$. mannii and leaves $(0.76 \pm 0.32 \%)$, stem $(0.79 \pm 0.92 \%)$, roots $(0.05 \pm 0.59 \%)$ of $D$. arborea.

Furthermore, Shukla et al. [31] reported a lipid content of $0.97 \pm 0.39 \%$ in the leaves of Dracaena reflexa.

Furthermore, Shukla et al. [31] reported a lipid content of $0.97 \%$ in the leaves of Dracaena reflexa. Compared to other edible leaves in the region, the lipid content found in this study is higher than those reported by Mawunu et al. [17] for Mondia whitei $(2.95 \pm 0.06 \%)$ and Pyrenacantha klaineana $(1.13 \pm 0.11 \%)$ leaves. The present results also indicate that $D$. camerooniana leaves are richer in lipids than those of Gnetum africanum $(2.45 \pm 0.15 \%)$ [34]. D. camerooniana is therefore an energetic leafy vegetable. Its lipids can increase palatability by absorbing and retaining flavours [25].

The protein content of three organs of $D$. camerooniana varied between $4.47 \%$ and $18.58 \% \mathrm{DM}$ (Table I). The protein results show a significant difference at the Tukey test $(\mathrm{P}<0.05)$. The leaves of $D$. camerooniana had the highest protein content $(18.58 \%)$ compared to the stems $(6.77 \%)$ and roots $(4.47 \%)$. Thus, the protein contents found in this study are higher than those reported by Ilodibia et al. [25] for leaves $(0.60 \%)$, stem $(0.21 \%)$, roots $(0.16 \%)$ of $D$. mannii and leaves $(0.51 \%)$, stem $(0.09 \%)$, roots $(0.10 \%)$ of D. arborea. Compared to other leaves consumed in the region, $D$. camerooniana leaves have a higher protein content (Table I) than those reported by Mawunu et al. [17] for Mondia whitei (16.48\% DM) and Pyrenacantha klaineana (14.93\%) leaves. On the other hand, Mbemba et al. [34] found a protein content of $4.86 \%$ for the leaves of Gnetum africanum. Also, this protein content is higher than that of Manihot esculenta (7.0\%) [35].

Protein is an important source of amino acids and is necessary for the development and maintenance of the body [36]. The results of this study on protein content are encouraging, as children of growing age, pregnant women, lactating mothers, and the elderly to compensate for the protein deficiency of the population especially in rural areas could consume D. camerooniana leaves.

Furthermore, the present results (Table I) show that the leaves, roots, and stems of $D$. camerooniana contain dietary fiber. The stems contained more dietary fiber $(53.65 \%)$ than the leaves $(14.20 \%)$ and roots $(11.94 \%)$.

However, the dietary fiber content found in this study is lower than those reported by Ilodibia et al. [25] for leaves $(35.08 \%)$, stem $(52.00 \%)$, roots $(55.01 \%)$ of D. mannii and leaves $(33.00 \%)$, stem $(42.06 \%)$ and roots $(30.09 \%)$ of $D$. arborea

Compared to other leaves consumed in the region, $D$. camerooniana leaves had a lower dietary fiber content than that reported by Mawunu et al. [17] for Pyracantha klaineana leaves $(40.45 \%)$. In addition, D. cameroonina leaves had a higher dietary fiber content than that reported by Mawunu et al. [17] for Mondia whitei leaves (13.16\%) and Shukla et al. [31] for Dracaena reflexa leaves (1.31\%). An adequate amount of dietary fiber makes it a good food since foods with high dietary fiber content facilitate digestion [35]. A good amount of fiber could have a considerable influence in the human digestive process to control constipation. Indeed, dietary fiber reduces the transit time of food in the intestine, which is why it is recommended for the local management of blood sugar, hypertension, and constipation. Also, fiber contributes to the prevention of type 2 diabetes, increases stool volume, stimulates colonic motricity and intestinal contraction, accelerates digestive transit by promoting the development of the microbiota and the production of intracolonial gas, which is partly at the origin of several pathologies affecting the colon, including stomach and colorectal cancer [37]. In addition, fiber has a positive effect on accelerating satiety, delaying the feeling of hunger, and thus limiting the risk of overeating, which helps prevent obesity [38]. Dietary fiber consumption also softens stools and reduces plasma cholesterol levels in the body [38], improves glycemic status and lipid profiles (mainly soluble fiber), reduces body weight and abdominal adiposity; chronic inflammation, cardiovascular risk, mortality; improves gut microbiota; colonic health and integrity and colonic motility [39].

Furthermore, the present results allow to classify the leaves, roots, and stems of $D$. camerooniana as plants rich in fiber; this makes $D$. camerooniana a food that could be interesting to participate in the prevention of digestive system cancers.

The carbohydrate content of the three organs studied in $D$. camerooniana ranged from $33.92 \%$ to $79.89 \%$ DM (Table I). The results on carbohydrates revealed a significant difference by Tukey's test $(\mathrm{P}<0.05)$. Roots contained the highest carbohydrate content $(79.89 \%)$ compared to leaves $(73.37 \%)$ and stems $(33.92 \%)$ of D. camerooniana. The carbohydrate content found in the present study is lower than that reported by Shukla et al. [31] for D. reflexa leaves $(86.01 \%)$.

On the other hand, the carbohydrate content in this study is higher than that reported by Ilodibia et al. [25] for leaves $(67.08 \pm 0.66 \%)$, stem $(41.10 \pm 0.73 \%)$, roots $(30.05 \pm 0.15 \%)$ of D. mannii and leaves $(69.07 \pm 0.53 \%)$, stem $(50.00 \pm 0.62 \%)$, roots $(32.06 \pm 0.74 \%)$ of $D$. arborea, respectively. 
Carbohydrates are important sources of energy for the brain, which depends on them for its proper functioning, just like many other organs in the body [40].

A high carbohydrate content indicates that the food is high in energy [17]. According to Yisa et al. [41], the main function of carbohydrates in the body is to provide energy for vital daily activities.

As for the amount of energy (kcal), the results in Table I show that the roots of $D$. camerooniana are more energetic $(315.41 \mathrm{kcal})$ than the leaves $(288.86 \mathrm{kcal})$ and the stems $137.60 \mathrm{kcal}$. The analysis on energy content (kcal) was revealed difference. Shukla et al. [31], found an energy content of about $367.56 \mathrm{kcal}$ in D. reflexa leaves. Mawunu et al. [17] analyzed the leaves of Mondia whitei and Pyrenacantha klaineana and found an energy content of $310.37 \mathrm{kcal}$ and $217.77 \mathrm{kcal}$, respectively.

Furthermore, the high energy content of the leaves and roots of $D$. camerooniana (edible parts) makes this plant a suitable source of energy for rural populations in northern Angola. In addition, the stems of $D$. camerooniana can be used as fodder for animals. It should be noted, however, that D. camerooniana leaves alone do not constitute a complete diet, hence, the need for diversification of the diet and combination of feeds. This observation corroborates that of other researchers such as Kahane et al. [42] who state that leafy vegetables are rarely consumed alone as such. This inseparable combination of a carbohydrate dish and a vegetable-based sauce has not only social and economic but also nutritional significance.

Furthermore, the high amount of energy found in the vegetative organs of $D$. camerooniana would be attributable to the high carbohydrate content [17]. The variability in the content of physico-chemical compounds reported in this study may be due to the harvesting season and the assimilative capacity of the different organs.

\section{2) Mineral Composition of D. camerooniana Organs}

\section{1) Macro-elements Composition}

Fig. 2 shows the results (mg/100 g dry matter (DM)) of five macronutrients analyzed in leaves, roots, and stems of $D$. camerooniana.

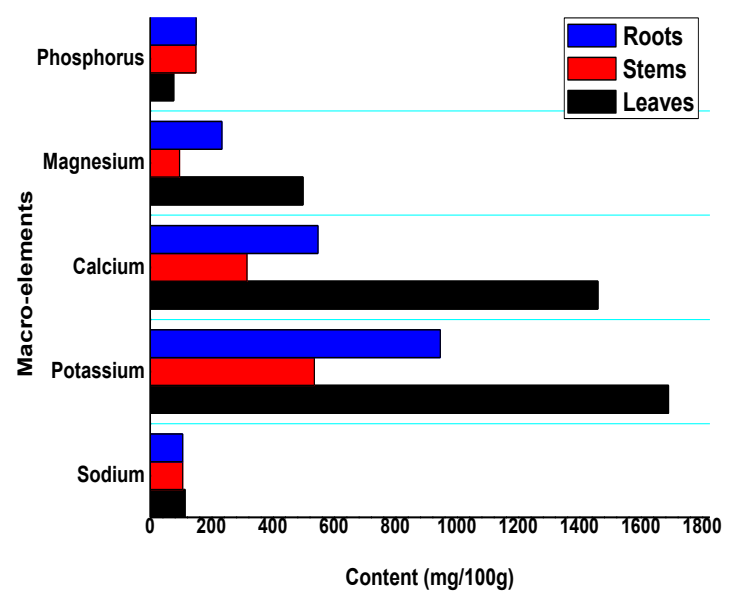

Fig. 2. Content of different organs of Dracaena camerooniana.

It can be seen from Fig. 2 that the sodium $(\mathrm{Na})$ content found in the leaves, roots, and stems of D. camerooniana varied from 105.83 to $113.60 \mathrm{mg} / 100 \mathrm{~g}$ dry matter.
The leaves of $D$. camerooniana had the highest $\mathrm{Na}$ content $(113.60 \mathrm{mg} / 100 \mathrm{~g})$ compared to roots $(106.30 \mathrm{mg} / 100 \mathrm{~g})$ and stems $(105.83 \mathrm{mg} / 100 \mathrm{~g})$.

The analysis on sodium content was revealed difference.

The leaves of $D$. camerooniana had the highest $\mathrm{Na}$ content $(113.60 \mathrm{mg} / 100 \mathrm{~g})$ compared to roots $(106.30 \mathrm{mg} / 100 \mathrm{~g})$ and stems $(105.83 \mathrm{mg} / 100 \mathrm{~g})$.

The Na content found in D. camerooniana leaves is higher than that reported by Mawunu et al. [17] for Mondia whitei leaves $(101.57 \mathrm{mg} / 100 \mathrm{~g})$, but lower for Pyrenacantha klaineana leaves (126.77 mg/100 g) Sodium plays an essential role in the conduction of nerve impulses alongside potassium [43].

Compared to the other main elements $(\mathrm{K}, \mathrm{P}, \mathrm{Ca}$, and $\mathrm{Mg}$ ) analyzed in this study, their sodium content was considered relatively low (Fig. 2). However, the sodium content determined in this study is comparable to previous work by Kibar and Temel [44].

On the other hand, excessive sodium intake is conducive to the induction of hypertension. An adequate intake of sodium is 1.2 to 1.5 grams per day [26].

The potassium $(\mathrm{K})$ content found in the leaves, roots, and stems of D. camerooniana varied between $535.07 \pm 0.20$ and $1690.00 \pm 0.17 \mathrm{mg} / 100 \mathrm{~g}$ dry matter.

The analysis on potassium content was revealed difference. The leaves of $D$. camerooniana have the highest $\mathrm{K}$ content $(1690.00 \mathrm{mg} / 100 \mathrm{~g})$ than the roots $(945.97 \mathrm{mg} / 100 \mathrm{~g})$ and stems $(535.07 \mathrm{mg} / 100 \mathrm{~g})$.

Compared to other leaves consumed in the region, $D$. camerooniana leaves had a higher K content than Mondia whitei leaves (1149.83 $\mathrm{mg} / 100 \mathrm{~g})$, but lower than Pyrenacantha klaineana $(2459.20 \mathrm{mg} / 100 \mathrm{~g})$ and Mondia whitei $(1149.83 \mathrm{mg} / 100 \mathrm{~g})$ [Mawunu et al. In the present results, potassium was found to be the most highly abundant mineral element (Fig. 2). As in most plant products the predominant mineral compound is potassium [45]. Similar conclusions were made by Mawunu et al. [17] and Özer and Aksoy [46]. According to Palmer [47], potassium plays an important role in the body, including the maintenance of body fluid balance and osmotic balance as well as the regulation of nerve signals and muscle concentrations.

The calcium $(\mathrm{Ca})$ content found in the leaves, roots, and stems of D. camerooniana varies between 315.87 and $1459.97 \mathrm{mg} / 100 \mathrm{~g}$ dry matter. The analysis on calcium content was revealed difference.

D. camerooniana leaves had the highest Ca concentration $(1459.97 \mathrm{mg} / 100 \mathrm{~g})$ compared to roots $(546.80 \mathrm{mg} / 100 \mathrm{~g})$ and stems $(315.87 \pm 0.07 \pm 0.20 \mathrm{mg} / 100 \mathrm{~g})$. Compared to other leaves consumed in the region, D. camerooniana leaves had a higher calcium content than those reported by Mawunu et al. [17] for Mondia whitei leaves $(844.87 \pm 0.09 \mathrm{mg} / 100 \mathrm{~g})$, but lower $(2126.33 \pm 0.09 \mathrm{mg} / 100 \mathrm{~g})$ for Pyrenacantha klaineana leaves. It should also be noted that the calcium content found in Dracaena camerooniana leaves is higher than that reported by Mbemba et al. [48] for Gnetum africanum $(520 \mathrm{mg} / 100 \mathrm{~g})$. Calcium is the most important mineral for humans and constitutes a major proportion of bones and teeth, human blood, and extracellular fluid [49].

It is required for normal functioning of the heart muscles, blood clotting and regulation of cell permeability. Calcium also plays a role in the transmission of nerve impulses and in 
the mechanism of the neuromuscular system [49]. Calcium contributes to the formation of strong, healthy bones and teeth [50]. However, calcium deficiency can lead to rickets, bone pain and muscle weakness [51].

D. camerooniana leafy vegetables can help to meet the daily calcium requirement of $260 \mathrm{mg}$ per day [52]. The data from this study on the $\mathrm{Ca}$ content of this wild plant could be an adequate source of $\mathrm{Ca}$ for human nutrition.

The magnesium $(\mathrm{Mg})$ content found in leaves, roots, and stems of $D$. camerooniana ranged from 95.41 to 498.83 . The analysis on magnesium content revealed difference.

D. camerooniana leaves had the highest $\mathrm{Mg}$ concentration $(498.83 \mathrm{mg} / 100 \mathrm{~g})$ compared to roots $(234.13 \mathrm{mg} / 100 \mathrm{~g})$ and stems $(95.41 \pm 0.10 \mathrm{mg} / 100 \mathrm{~g})$.

Compared to other leaves consumed in the region, $D$. camerooniana leaves have a higher $\mathrm{Mg}$ content than those reported by Mawunu et al. [17] for Pyrenacantha klaineana (241.93 mg/100 g) and Mondia whitei (219.90 mg/100 g), and also for Manihot esculenta (31 mg/100 g) [53]. On the other hand, the Mg content of Gnetum africanum $(160 \mathrm{mg} / 100 \mathrm{~g})$ is higher than that of Dracaena camerooniana leaves [48]. Leaves are the main sites of photosynthesis in higher plants. Moreover, magnesium is an integral part of chlorophyll. This could justify the high $\mathrm{Mg}$ content in leaves rather than in other organs.

In addition, magnesium helps relax the muscles along the airways, allowing asthmatics to breathe with ease [54]. According to Elinge et al. [55], magnesium is a major constituent of bones and teeth alongside calcium and phosphorus; it is also necessary for tissue respiration, the release of parathyroid hormone and its action in the spine, intestine, and kidneys. Thus, consumption of $D$. camerooniana leaves may help prevent magnesium-related health problems.

The phosphorus $(\mathrm{P})$ content found in the analyzed organs (leaves, roots, and stems) of $D$. camerooniana varied between 76.72 and $149.56 \mathrm{mg} / 100 \mathrm{~g}$ dry matter. The analysis on phosphorus content reveals a difference in tree organs. The $\mathrm{P}$ content found in the roots of $D$. camerooniana $(149.56 \mathrm{mg} / 100 \mathrm{~g})$ is close to that of the stems $(149.00 \mathrm{mg} / 100 \mathrm{~g})$ and the lowest content observed is in the leaves $(76.72 \mathrm{mg} / 100 \mathrm{~g})$. Compared to other leaves consumed in the region, D. camerooniana leaves have a lower $\mathrm{P}$ content than that reported by Mawunu et al. [17] for Pyrenacantha klaineana $(239.90 \pm 0.06 \mathrm{mg} / 100 \mathrm{~g})$ and Mondia whitei $(175.89 \pm 0.17 \mathrm{mg} / 100 \mathrm{~g})$; by Mbemba et al. [48] for Gnetum africanum (1340 mg/100 g); [53] for Manihot esculenta (84 mg/100 g).

Phosphorus is the most abundant mineral element in the body after calcium. Phosphorus regulates various physiological functions, including skeletal development, energy transfer through mitochondrial metabolism and blood plate aggregation [49]. The phosphorus content observed in this study varies between different organ types. Finally, the results of this study suggest that $D$. camerooniana leaves are a significant source of phosphorus for people who consume them.

\section{2) Oligo Elements Composition}

Fig. 3 shows the trace elements composition of different organs (leaves, roots, and stems) of D. camerooniana in $\mathrm{mg} / 100 \mathrm{~g}$ dry matter (DM).

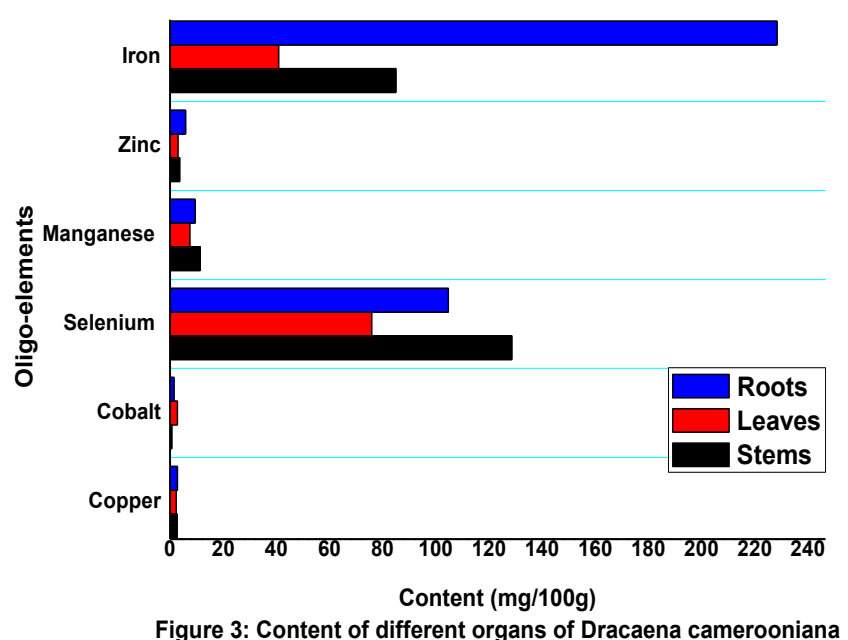

Fig. 3. Content of different organs of Dracaena camerooniana.

The analysis on copper content was revealed difference. The copper $(\mathrm{Cu})$ content found in the organs of $D$. camerooniana varied between 2.30 and $2.80 \mathrm{mg} / 100 \mathrm{~g}$ dry matter. The results in Fig. 3 show that the roots of $D$. camerooniana are richer in copper $(2.80 \mathrm{mg} / 100 \mathrm{~g})$ compared to the leaves $(2.65 \mathrm{mg} / 100 \mathrm{~g})$ and stems $(2.30 \mathrm{mg} / 100 \mathrm{~g})$. Compared to other leaves consumed in the region, $D$. camerooniana leaves had a lower copper content than those reported by Mawunu et al. [17] for Mondia whitei $(3.14 \pm 0.04 \mathrm{mg} / 100 \mathrm{~g})$ and Pyrenacantha klaineana $(2.84 \pm 0.04 \mathrm{mg} / 100 \mathrm{~g})$ leaves.

Copper is a trace element necessary for the activity of several key enzymes, including cytochrome oxidase and superoxide dismutase. In addition, copper is involved in the host cell defence mechanism, maturation of white and red blood cells, myocardial contractility, and brain development [56]. The results of this study indicate that Dracaena camerooniana leaves can be used as a source of copper in the human diet.

The cobalt (Co) content found in the organs of $D$. camerooniana varied between 0.65 and $2.80 \mathrm{mg} / 100 \mathrm{~g}$ dry matter. The analysis on cobalt content was revealed difference. The stems of $D$. camerooniana are richer in cobalt $(2.80 \mathrm{mg} / 100 \mathrm{~g})$ compared to roots $(1.50 \mathrm{mg} / 100 \mathrm{~g})$ and leaves $(0.65 \mathrm{mg} / 100 \mathrm{~g})$.

Compared to other leaves consumed in the region, $D$. camerooniana leaves have a lower Co content than those reported by Mawunu et al. [17] for Pyrenacantha klaineana $(2.84 \pm 0.2 \mathrm{mg} / 100 \mathrm{~g})$ and Mondia whitei $(2.73 \pm 0.05 \mathrm{mg} /$ $100 \mathrm{~g}$ ) leaves. Cobalt is an integral part of vitamin B12 [57] and is therefore essential for cell function. It is also involved in the production of red blood cells and antibacterial and antiviral compounds that prevent infections [58]. Cobalt also plays a key role in the metabolism of fats and carbohydrates and in the synthesis of folate in its active form. Cobalt ensures optimal absorption of iron by the cells. In the nervous system, cobalt is responsible for the prevention of demyelination leading to multiple sclerosis, which is a condition that causes 
damage to the membrane covering the nerve fibrils in the brain and spinal cord. This prevention ensures the efficient transmission of nerve impulses [57], [58].

The cobalt content found in $D$. camerooniana makes this wild edible plant a food for both humans and livestock. Consumption of this plant can be used to prevent diseases related to cobalt deficiency.

The analysis on selenium content was revealed difference. The selenium (Se) content found in the three analyzed organs of D. camerooniana varied between 75.87 and $128.51 \mathrm{mg} /$ $100 \mathrm{~g}$ dry matter.

The leaves of $D$. camerooniana are richer in selenium $(128.51 \mathrm{mg} / 100 \mathrm{~g})$ than the roots $(104.69 \mathrm{mg} / 100 \mathrm{~g})$ and stems $(75.87 \mathrm{mg} / 100 \mathrm{~g})$. Compared to other leaves consumed in the region, $D$. camerooniana leaves have higher selenium content than those reported by Mawunu et al. [17] for Mondia whitei $(87.80 \pm 0.12 \mathrm{mg} / 100 \mathrm{~g})$ and Pyrenacantha klaineana (77.86 $\pm 0.11 \mathrm{mg} / 100 \mathrm{~g})$ species.

Selenium is an element in trace form that is essential for life, it protects the cells against free radicals and participates in the detoxification of heavy metals and in the regulation of the immune and reproductive system [59]. Selenium also supports the thyroid gland and the body's antioxidant defense mechanism [59].

The richness of selenium found in $D$. camerooniana leaves makes this leafy vegetable a food that could be interesting to participate in the prevention of cardiovascular diseases through its antioxidant properties.

The manganese $(\mathrm{Mn})$ content found in the vegetative organs of D. camerooniana varied from 7.41 to $11.39 \mathrm{mg} /$ $100 \mathrm{~g}$ dry matter. The leaves of $D$. camerooniana are more concentrated in $\mathrm{Mn}(11.39 \mathrm{mg} / 100 \mathrm{~g})$ in relation to the roots $(9.44 \mathrm{mg} / 100 \mathrm{~g})$ and stems $(7.41 \mathrm{mg} / 100 \mathrm{~g})$. The analysis on manganese content was revealed difference.

Compared to other leaves consumed in the region, $D$. camerooniana leaves had higher manganese content than those reported by Mawunu et al. [17] for Pyrenacantha klaineana leaves $(6.14 \mathrm{mg} / 100 \mathrm{~g})$ and Mondia whitei (5.11 mg/100g DM).

The zinc $(\mathrm{Zn})$ content found in the analyzed organs of $D$. camerooniana varied between 2.94 and $5.83 \mathrm{mg} / 100 \mathrm{~g}$ dry matter. The present results (Fig. 3) show that, the roots of $D$. camerooniana are richer in zinc $(5.83 \mathrm{mg} / 100 \mathrm{~g})$ compared to leaves $(3.65 \mathrm{mg} / 100 \mathrm{~g})$ and stems $(2.94 \mathrm{mg} / 100 \mathrm{~g})$. The analysis on zinc content was revealed difference. Compared to other leaves consumed in the region, D. camerooniana leaves have higher zinc content than those reported by Mawunu et al. [17] for Pyrenacantha klaineana $(3.47 \mathrm{mg} /$ $100 \mathrm{~g}$ ) and Mondia whitei (1.42 mg) leaves According to Bello et al. [54], zinc is mainly related to protein synthesis, the catalytic activity of several enzymes and to rapid growth and development during infancy, adolescence, and wound healing. In addition, zinc is a stabilizer and stimulator of the immune response. However, its deficiency leads to growth retardation and poor development of gonadal function [60].

The iron $(\mathrm{Fe})$ content found in the different organs analyzed of D. camerooniana varies between 40.88 and $228.30 \mathrm{mg} / 100 \mathrm{~g}$ dry matter. The analysis on iron content was revealed difference. Roots had the highest iron content $(228.30 \mathrm{mg} / 100 \mathrm{~g})$ compared to leaves $(84.98 \mathrm{mg} / 100 \mathrm{~g})$ and stems (40.88 mg/100 g).
Compared to other leaves consumed in the region, $D$. camerooniana leaves had higher iron content than those reported by Mawunu et al. [17] for Pyrenacantha klaineana (21.69 mg/100 g), Mondia whitei (14.21 mg/100 g); by Mbemba et al. [48] for Gnetum africanum (20.38 mg/100 g) and Manihot esculenta $(1.8 \mathrm{mg} / 100 \mathrm{~g})$, respectively. According to Elinge et al. [55], iron has several important functions in the body including blood formation and transport of oxygen and carbon dioxide to tissues [54]. Moreover, wild green leafy vegetables increase the amount of blood in the body, which probably refers to the high iron content of many wild green vegetables [61]. Iron plays a role in the synthesis of chlorophyll [62]. The high iron content of $D$. camerooniana leaves could be a strong argument for recommending them as a health food to combat diseases associated with iron deficiency (anaemia).

The variation in mineral content observed in the leaves, roots, and stems of Dracaena camerooniana would be attributed to the assay capabilities of each plant organ and the geological environment of the habitat. El Hajajil et al. [63] reported that significant variations in tissue mineral content can occur depending on the organs analyzed (roots, bark, flowers, fruits, and leaves) of the plant.

Furthermore, Jarrige et al. [18] concluded that the mineral content of the plant depends on the soil, the availability of each element to the plant, and the efficiency of root uptake to the aerial organs of the plant.

\section{CONCLUSION AND RECOMMENDATIONS}

The present study was aimed at conducting a nutritional study of Dracaena camerooniana Baker.

The results of this study showed that:

- The leaves contain water (86.89\%), ash (15.59\%), lipids $(5.42 \%)$, protein $(18.58 \%)$ and the energy value are estimated at $416.59 \mathrm{kcal}(1743.013$ kilojules).

- The leaves are richer in potassium $(1690.00 \mathrm{mg} /$ $100 \mathrm{~g})$, calcium $(1459.97 \mathrm{mg} / 100 \mathrm{~g})$, magnesium $(498.83 \mathrm{mg} / 100 \mathrm{~g})$, selenium $(128.51 \mathrm{mg} / 100 \mathrm{~g})$ and manganese $(11.39 \mathrm{mg} / 100 \mathrm{~g})$. However, the stems are richer in fiber $(53.65 \%)$ and cobalt $(2.80 \mathrm{mg} /$ $100 \mathrm{~g})$. On the other hand, the roots are richer in carbohydrates $(79.89 \%)$, phosphorus (149.56 mg / $100 \mathrm{~g})$, zinc $(5.83 \mathrm{mg} / 100 \mathrm{~g})$ and iron $(228.30 \mathrm{mg} /$ $100 \mathrm{~g})$.

- The richness of various nutrients contained in the organs of $D$. camerooniana proves that the consumption of this wild plant can contribute to the improvement of the nutritional status of the population, especially in anaemic people.

- Also, phytochemical studies and bioassays need to be conducted to discover the medicinal properties of this plant. Domestication of the plant should be done to ensure its conservation both in situ and ex situ with the support of local farmers. Thus in vitro micro-propagation would make healthy material available for domestication while the genetic diversity it represents is still available in its natural habitat. 


\section{COMPETING INTERESTS DISCLAIMER}

Authors have declared that no competing interests exist. The products used for this research are commonly and predominantly use products in our area of research and country. There is absolutely no conflict of interest between the authors and producers of the products because we do not intend to use these products as an avenue for any litigation but for the advancement of scientifical knowledge. Also, the research was not funded by the producing company rather it was funded by personal efforts of the authors.

\section{REFERENCES}

[1] B. Burlingame, (Editor). Editorial. Wild Nutrition. Journal of Food Composition and Analysis, vol.2, 13, 99-100, 2000.

[2] B. Belcher, Ruíz-Pérez M., R. Achidiawan, Global patterns and trends in the use and management of commercial NTFPs. World Development, Vol. 33, 9, 1435-1452, September 2005. https://doi.org/10.1016/j.worlddev.2004.10.007.

[3] B. Vincetti, Eyzaguirre P., T. Johns, The nutritional role of forest plant foods for rural communities. In Human health and forests: a global overview of issues practice and policy $\left(1^{\text {st }}\right.$ eds.) Coler C. J. P., London, UK: Earthscan. pp. 63-96, 2008.

[4] R. Barnett, Food for thought: the utilization of wild meat in Eastern and Southern Africa. TRAFFIC East and Southern Africa, Nairobi: IUCN and WWF. 264p, 2000.

[5] S. Beluhan and A. Ranogajec, Chemical composition and non-volatile components of Croatian wild edible mushrooms. Food Chemistry, 124:1076-1082,2010. DOI: 10.1016/j.foodchem.2010.07.081.

[6] G. Addis, Edible wild and semi-wild plants of Hamar and Xonso (South Ethiopia) with emphasis on their ethnobotany and nutritional composition of selected species, [Ph.D. Thesis], Addis Ababa University, Addis Ababa, Ethiopia, 2009.

[7] Quebedeaux, B., \& Eisa, H.M., (1990). Horticulture and human health Contributions of fruits and vegetables. Proc. 2nd Intl. symp. Hort. and Human Health. Hort Science 25,1473-1532.

[8] N. Sekeroglu, F. Ozkutlu, M. Deveci, O. Dede, and N. Yilmaz, "Evaluation of some wild plants aspect of their nutritional values used as vegetable in Eastern Black Sea Region of Turkey," Asian Journal of Plant Sciences, vol. 5, no. 2, pp. 185-189, 2006. DOI: 10.3923/ajps.2006.185.189.

[9] H.T. Duguma, Wild Edible Plant Nutritional Contribution and Consumer Perception in Ethiopia. International Journal of Food Science, Volume 2020, Article ID 2958623, 16 p, 2020. DOI: 10.1155/2020/2958623.

[10] S. Chakravarty, K. D. Bhutia, C. P. Suresh, G. Shukla, and N. A. Pala. "A review on diversity, conservation and nutrition of wild edible fruits," Journal of Applied and Natural Science. vol. 8, no. 4, pp. 23462353. DOI: 10.31018/jans.v8i4.1135, December 2016.

[11] M. Mawunu, P. Macuntima, T. Lautenschläger, L. Masidivinga, N. Luyindula, K. N. Ngbolua and L. Lukoki. First Survey on the Edible Non-Wood Forest Products Sold in Uíge Province, Northern Angola European Journal of Agriculture and Food Sciences. Vol. 2. No.6, 2020b. Doi.org/10.24018/ejfood.2020.2.6.135.

[12] M. Monizi, André Canga D., Luyeye L., Ngbolua K.N., L. Ndiku, Ethnobotanical and Socio-economics of Dracaena camerooniana Baker in Uíge Province, Northern Angola. Journal of Agriculture and Ecology Research International, (2): 1-15, 2019. DOI: 10.9734/jaeri/2019/v20i230104.

[13] M. Mawunu, Bongo K., Afonso E., Makonzo M. ZA VUA, Luyindula N., KN Ngbolua, Contribution to the knowledge of non-wood forest products of the Municipality of Ambuila (Uíge, Angola): Wild plants edible. International Journal of Innovation and Scientific Research, Vol. 26 No. 1 Aug. pp. 190-204, August 2016.

[14] F. K. Huber, R. Ineichen, Y. P. Yang, and C. S. Weckerle. "Livelihood and conservation Aspects of Non-wood Forest Product Collection in the Shaxi Valley, Southwest China1," Economic Botany, vol. 64, no. 3, pp. 189-204, 2010. https://doi.org/10.1155/2020/2958623.

[15] K. Jayanti, Agarwal and P. Saini, Nutritional Assessment of Leaves of Wild edible plant Urtica ardence. Indian Journal of Pharmaceutical and Biological Research, Vol. 1, (2) 53-59, December 2013.

[16] K. Balemie and F. X. Kebebew, "Ethnobotanical study of wild edible plants in Derashe and Kucha Districts, South Ethiopia". Journal of Ethnobiology and Ethnomedicine. Vol. 2, 53, December 2006. https://doi.org/10.1186/1746-4269-2-53.
[17] M. Mawunu, M. Pedro, T. Lautenschläger, FM Biduayi, PM Kapepula, KN Ngbolua, FL Luyeye and N. Luyindula, Nutritional Value of Two Underutilized Wild Plant Leaves Consumed as Food in Northern Angola: Mondia whitei and Pyrenacantha klaineana. European Journal of Nutrition \& Food Safety, 12 (8): 116-127, 2020a. DOI: 10.9734/ejnfs/2020/v12i830276.

[18] R. Jarrige, Ruckebusha Y., C. Demarquilly, Ruminant herbivores. The nutrition of domestic ruminants; ingestion and digestion. Ed. INRA, 7$27 \mathrm{p}, 1995$.

[19] P. Ertan, Yereli K., Kurt O., Balcıoglu I. C., A. Onag, Serological levels of zinc, copper and iron element among Giadia lamblia injected children in Turkey. Pediatrics International, 44, 286-288, 2002. DOI:10.1046/j.1442-200X.2002.01550.x.

[20] M. Monizi M., Lautenschläger T., Fernando J., Heitor MT, Luyindula N., Lukoki LF, K.N. Ngbolua, Traditional knowledge and skills in rural Bakongo communities: a case study in the Uíge province, Angola. American Journal of Environment and Sustainable Development Vol.3. No. 3, pp33-45, 2018. DOI: 10.9734/jaeri/2019/v20i230104.

[21] AOAC, Association of Official Analytical Chemists. Official methods of analysis, 17th ed. Association of Official Analytical Chemists, Gaithersburg. 2000.

[22] M. Asaduzzaman, M. M. Hasan, and M. Moniruzzaman, Quality seed production of onion (Allium cepa L.): an integrated approach of bulb size and plant spacing. Journal of Agricultural Research, vol. 50(1), pp. 119-128, 2012.

[23] AOAC, Association of Official Analytical Chemists. Official methods of analysis, association of official analytical chemists, Washington DC, USA, 2019, 18th edition. 2019

[24] AOAC, Official Methods of Analysis of Association of Official Analytical Chemists, 15th ed., Arlington Va, USA: AOAC, pp. 1-50, 1990.

[25] V. Ilodibia Chinyere, Ugwu U. Rachael, C. U. Okeke, Chinelo A. Ezeabara, Nneka F. Okeke, Ebele E. Akachukwu and Bibian O. Aziagba. Determination of Proximate composition of Various Parts of Two Dracaena species. International Journal of Botany, 10 (1): 37-41, 2014. DOI: $10.3923 / \mathrm{ijb} .2014 .37 .41$

[26] Food and Nutrition Board Dietary. Reference Intake for Water Potassium, Sodium, Chloride and Sulfate. Institute of Medicine, National Academies, Washington, DC. National Academies Press, 2005.

[27] P. Dorosz, Vitamins, minerals, trace elements. Ed. Maloine, Paris, 101p, 1991.

[28] L. Depesay, Vegetables in the diet: their nutritional effects. Louis Bonduelle Foundation, September 2007.

[29] R. O. Fennema and S. R. Tannenbaum, Introduction to Food chemistry. In: Food chemistry, Fennema S. R., M. Karel, G. W. Sanderson, S. R. Tennenbaum, P. Walstra and J. R. Witaker (Eds.). Marcel Dekker Inc., New York, pp: 1-64, 1996.

[30] W.W. Desrosier and J. N. Desrosier, The Technology of Food Preservation. Westport, Connecticut: AVI publication, 23, 1, 1997.

[31] A. Shukla, Vats S., and R. K. Shukla, Phytochemical Screening, Proximate Analysis and Antioxidant Activity of Dracaena reflexa Lam. Leaves. Indian Journal of Pharmaceutical Sciences, 77 (5): 640644. Sept-Oct 2015.

[32] R. Gonza'lez-Barrio, Periago M. J., Luna-Recio C., Garcia-Alonso F. J., I. Navarro-Gonza'lez. 2018. Chemical composition of the edible flowers, pansy (Viola wittrockiana) and snapdragon (Antirrhinum majus) as new sources of bioactive compounds. Food Chemistry, 252: 373-380, 2018. DOI: 10.1016/j.foodchem.2018.01.102.

[33] World Health Organization (WHO). Global Action against Cancer Now. Geneva, Switzerland. ISBN: 9789241593144, p.24, 2005.

[34] F. Mbemba, J. M. Moutsambote, J. M. Nzikou, M. Mvoula-Tsiery, S Y. Itoua Okouango, I. Nganga, Z. Mboungou, Th. Silou, Physical Factures Nutritional Value of the Traditional Picking Vegetable, Cuervea isangiensis (De wild.) N. hallé in Congo Brazzaville. Advance Journal of Food Science and Technology, 5 (1): 72-76, 2013. DOI: 10.5897/AJFS2019.1811.

[35] M. Ndong, S. Wade, N. Dossou, A. T. Guiro, R. D. Gning, Nutritional value of Moringa oleifera, study of the bioavailability of iron, enrichment effect of various traditional Senegalese dishes with leaf powder. African journal of Food Agriculture Nutrition and Development. vol. 7, no. 3, 2007.

[36] D. M. Dreon, Vranizan K. M., Krauss R. M., Austin M. A., P.D. Wood. The effects of polyunsaturated fat monounsaturated fat on plasma lipoprotein. Journal of American Medical Association, 263, 24622466, 1990. DOI:10.1001/jama.1990.03440180068034.

[37] M. Achaglinkame Atongbiik, Aderibigbe R. Olaide, Hensel O., Sturm B. and J. Kudadam Korese, Nutritional Characteristics of Four Underutilized Edible Wild Fruits of Dietary Interest in Ghana. Foods, 8, 104, 2019. DOI:10.3390/foods8030104. 
[38] R. Guiné, Duarte J., Ferreira M., Correia P., Leal M., Rumbak I., Komes D., Satalic Z., Saric M.M., Tarcea M., Fazakas Z., Jovanoska D., Vanesvski D., Vittadini E, Pellegrini N, Szucs V, Harangozó J, ELKenawy A, EL-Shenawy O., Yalçin E., Kösemeci C., Klava D., E. Straumite, Benefits of dietary fiber to human health: study from a multi-country platform. Nutrition \& Food Science, 47 (5), 688-699, 2017. DOI:10.1108/NFS-11-2016-0165.

[39] M. T. Barber, S. Kabisch, Andreas F. H. Pfeiffer, and Martin O. Weickert, The Health Benefits of Dietary Fibre: Review. Nutrients. 12, 3209, 2020. DOI: 10.3390/nu12103209.

[40] E. Jéquier, Carbohydrates as a source of energy. American Journal of Clinical Nutrition.,59 (3Suppl):682s-685s, March 1994. DOI: 10.1093/ajcn/59.3.682S.

[41] J. Yisa, Egila J. N., A. O. Darlinton. Chemical composition of Annona senegalensis from Nupe land, Nigeria. African Journal of Biotechnology, $9 \quad$ (26): $4106-4109$, June 2010 Doi.org/10.5897/AJB2010.000-3292.

[42] R. Kahane, Temple L., Brat P., H. DE Bon, Leaf vegetables from tropical countries: diversity, economic wealth and health value in a very fragile context. Angers Symposium September 7-9, 2005-03-14. Vegetables: A heritage to transmit and promote. Theme III: Use and perception, 2005.

[43] A. Al-Farga, Zhang H., Siddeeg A, Shamoon M., Chamba M. V., N. Al-Hajj, Proximate composition, functional properties, amino acid, mineral and vitamin contents of a novel food: alhydwan (Boerhavia elegana Choisy) seed flour. Food Chemistry, 211: 268-273, 2016. DOI:10.1016/j.foodchem.2016.05.016.

[44] B. Kibar and S. Temel, Evaluation of mineral composition of come wild edible plants growıng in the eastern Anatolia Regıon Grasslands of Turkey and consumed as vegetable. Journal of Food Processing and Preservation, 40 (1), 56-66, 2016. Doi.org/10.1111/jfpp.12583.

[45] C. Ibrahima, Characterization of the nutritional biochemical properties of Baobab pulp of endemic species from Madagascar and continental Africa with a view to their valorization. Doctoral thesis, Montpellier Sup Agro. France, 2012.

[46] M. Özer and M. Aksoy, Mineral composition and nutritional properties of Trachystemon orientalis (L.) G. Don populations in the Central Black Sea Region of Turkey. Acta Scientiarum Polonorum Hortorum Cultus, 8 (4), 157-167, 2019. DOI : 10.24326/asphc.2019.4.15.

[47] B. F. Palmer, Regulation of potassium homeostasis. Clinical Journal of the American Society Nephrology, 10, 1050-1060, 2015. DOI: $10.2215 /$ CJN.08580813.

[48] F. Mbemba, N. K. Tatola, S. Y. Itoua Okouango, J. M. Moutsambote, M. Mvoula-tsieri, Th. Silou, Composition in Mineral Elements of the Traditional Vegetables Leaves of Cuervea isangiensis (de wild.) N. hallé in Congo-Brazzaville. Current Research Journal of Biological Sciences, vol-4, (6): 738-742, 2012

[49] Y. S. Rana, Tiwari O. P., Krishan R. and C. M. Sharma, Determination of nutritional potential of five important wild edible fruits traditionally used in Western Himalaya. International Journal of Life Sciences, Volume 6 (1): 79-86, February 2018.

[50] K. O. Soetan, C. O. Olaiya and O. E. Oyewole, The importance of mineral elements for humans, domestic animals and plants: A review. African Journal of Food Science, Vol. 4 (5), pp. 200-222, May 2010.

[51] J. S. Alakali, C. T. Kucha and I. A. Rabiu. Effect of drying temperature on the nutritional quality of Moringa oleifera leaves. African Journal of Food Science, 9 (7), pp. 395-399, 2015. Doi.org/10.5897/AJFS2014.1145.

[52] Food and Agricultural Organization of the United Nations (FAO) /World Health Organization (WHO). 2001. Human Vitamin and Mineral Requirements, 268p, 2001.

[53] M. Broin, Nutritional composition of Moringa oleifera, Moringaceae.1-5p, 2012.

[54] M. O. Bello, Falade O. S., Adewusi S. R. A., N. O. Olawor, Studies on the chemical compositions and anti-nutrients of some lesser known Nigeria fruits. African Journal of Biotechnology, 7, 3972-3979, 2008.Doi.org/10.5897/AJB2008.000-5071.

[55] C. M. Elinge, Muhammad A., Atiku F. A., Itodo A. U., Peni I. J., Sanni O. M., A. N. Mbongo, Proximate, mineral and anti-nutrient composition of pumpkin (Cucurbita pepo L.) seeds extract. International Journal Plant Research, 2,146-150, 2012. Doi: 10.5923/j.plant.20120205.02.

[56] Food standards agency. Safe Upper Levels for Vitamins and Minerals: Report of the Expert Group on Vitamins and Minerals. Food Standards Agency, London, UK. 360p, 2003.

[57] Health library.www.m.netmeds.com Download on 03 March 2021, 2012.

[58] K. Czarnek, Sylwia Terpilowska, Andrzej K. Siwicki, Selected aspects of the action of cobalt in the human body. Central European Journal of Immunology, 40 (2): 236-242, 2015. DOI: 10.5114/ceji.2015.52837.

[59] M. Kieliszek and S. Błazejak, 2016. Current Knowledge on the Importance of Selenium in Food for Living Organisms: A Review. Molecules, 21, 609, 2016. DOI: 10.3390/molécules21050609.

[60] J. N. Ihedioha, C.O.B. Okoye, Nutritional evaluation of Mucuna flagellipes leaves: An underutilized legume in Eastern Nigeria. American Journal of Plant Nutrition and Fertilization Technology. 1 (1): 55-63, 2011. DOI: 10.3923/ajpnft.2011.55.63.

[61] S. Misra, Maikhuri R.K., Kala C.P., Rao K.S. and K.G. Saxena, Wild leafy vegetables: A study of their subsistence dietetic support to the inhabitants of Nanda Devi Biosphere Reserve, India. Journal of ethnobiology and ethnomedicine, 4:15, 2014. Doi.org/10.1186/17464269-4-15.

[62] J. Simpkins and Williams U. S. A Textbook of Biology, Third Edition. Editor.: HarperCollins , ISBN 10: 0003222764, 1992.

[63] H. El Hajajil, Farah A., Ennabili A., Bousta D., Greche H. El Bali B., M. Lachkar, Comparative study of the mineral composition of the constituents of three categories of (Ceratonia siliqua L.). Journal of Materials and Environmental Science, 4 (2) 165-170, 2013. 